\title{
ANATOMI TEORI HEGEMONI ANTONIO GRAMSCI
}

\author{
Endah Siswati \\ Universitas Islam Balitar \\ Jl. Majapahit No.4 Blitar, Jawa Timur 66139 \\ Email: endah.siswati@yahoo.co.id
}

\begin{abstract}
Antonio Gramsci is a great intellectual among the left, who is called the greatest thinker after Karl Marx. Gramsci's ideas are contained in many articles published in the mass media, and in his works such as; Prison Notebook, The Modern Prince and Other Political Writing, Selection from Prison Notebooks, Letters from Prison, Selection from Political Writing, Selection from Cultural Writing, and so on.

Of all the works and writings, hegemony is considered as the central and original idea developed by Gramsci. The hegemonic theory is seen to have brought about great change and led to a debate of thought over theories of social change, especially for those who want radical and revolutionary change.

Gramsci's concepts of hegemony, civil society, political society, counterhegemony, war of position, war of movement, organic intellectuals and their role in social transformation are ideas that are considered brilliant, and make important contributions to the development of social theories, and foster critical political awareness. His concept of hegemony also encouraged the re-formulation of class character, the social forces and the true meaning of power and domination. These things are the basis of writing this article.
\end{abstract}

Keywords: hegemony, counter hegemony, civil society, political society, intelectual organic.

\begin{abstract}
ABSTRAK
Antonio Gramsci adalah seorang intelektual besar di kalangan kaum kiri, yang disebut sebagai pemikir terbesar setelah Karl Marx. Pemikiran-pemikiran Gramsci tertuang dalam banyak artikel yang dimuat di media massa, dan dalam buku-buku karyanya seperti; Prison Notebook, The Modern Prince and Other Political Writing, Selection from the Prison Notebooks, Letters from Prison, Selection from Political Writing, Selection from Cultural Writing, dan sebagainya.

Dari seluruh karya dan tulisannya, hegemoni dinilai sebagai ide sentral dan orisinal yang dikembangkan Gramsci. Teori Hegemoni dipandang telah membawa perubahan besar dan menimbulkan perdebatan pemikiran atas teori-teori perubahan sosial, terutama bagi yang menghendaki perubahan radikal dan revolusioner.

Konsep-konsep pemikiran Gramsci tentang hegemony, civil society, political society, counter hegemony, war of position, war of movement, intelectual organik dan perannya dalam transformasi sosial, adalah gagasan-gagasan yang dinilai brilian, dan memberi sumbangan penting pada perkembangan teori-teori sosial, dan menumbuhkan kesadaran politik kritis. Konsep pemikirannya tentang hegemoni
\end{abstract}


juga mendorong perumusan kembali watak kelas, kekuatan-kekuatan sosial dan makna sejati dari kekuasaan dan dominasi. Hal-hal inilah yang antara lain mendasari penulisan artikel ini.

Kata kunci: hegemony, counter hegemony, civil society, political society, intelectual organic.

\section{a. Konteks Sosial Politik dan Fenomena Sosial yang Melahirkan Teori Hegemoni Gramsci}

Gramsci bukan filsuf yang melahirkan teori hanya dari kontemplasi, tetapi dari pengalaman, pengamatan, dan interpretasi kehidupan sosial politik dan fenomena sosial yang berlangsung di sekitar kehidupannya. Untuk mengetahui konteks sosialpolitik dan fenomena sosial yang melatarbelakangi kemunculan teori hegemoni Gramsci, maka harus dilacak perkembangan kondisi sosial politik di Italia pada masa kehidupan Gramsci.

Pada saat Gramsci memulai aktifitas kuliah di Turin, Gramsci untuk pertama kalinya menjumpai kehidupan kota industri modern. Turin adalah kota industri yang bergelimang kemewahan, dan sangat bertolak belakang dengan kehidupan di desa pertanian. Gramsci juga melihat hubungan sosial politik yang timpang antara kelas buruh di kota dan petani di desa. Perbedaan yang tajam tersebut melanggengkan konflik antara daerah industri 'Utara' dan kawasan pedesaan 'Selatan'. Kemiskinan dan ketidakadilan yang dialami Gramsci sejak kecil di daerah Selatan, membentuknya menjadi seorang revolusioner, yang aktif melakukan perjuangan politik di Turin. Gramsci tidak hanya menuangkan ide-ide intelektual, tetapi juga terlibat dengan organisasi-organisasi massa militant. Gramsci selalu menuliskan setiap aspek masyarakat Turin dan kondisi sosial politiknya, sekaligus menganalisa sejumlah pemogokan dan demonstrasi buruh di Turin, serta peristiwa politik lainnya di Italia maupun dunia internasional.

Agustus 1917, meletus pemberontakan buruh spontan di Turin. Para buruh bangkit dan mengepung pusat kota. Pemberontakan selama empat hari yang menewaskan sekitar 50 orang buruh dan membuat ratusan buruh lainnya dipenjara ini, menunjukkan militansi dan jiwa revolusioner masyarakat Turin yang luar biasa, dan peristiwa ini mempunyai arti politik yang luar biasa dan memberi kesan 
mendalam bagi Gramsci. Gerakan perlawanan buruh di Turin terus berlanjut sepanjang tahun 1919-1920. Gerakan yang kemudian dikenal dengan sebutan Gerakan Dewan Pabrik ini, memberikan pengalaman berharga dalam aktifitas gerakan buruh.

Ketika Perang Dunia I berakhir, situasi ekonomi Italia terpuruk, buruh menjadi makin menderita, dan keresahan sosial merebak di seluruh Italia. Para buruh pabrik baju di Turin diradikalisasi oleh perang. Mereka bereaksi dengan mendirikan organisasi oposisi melawan organisasi staf pabrik yang sudah ada. Gerakan ini meluas ke pabrik-pabrik lain, termasuk ke pabrik mobil Fiat, perusahaan otomotif besar di Italia. Gerakan ini juga melebihi serikat-serikat buruh reformis yang umumnya dikuasai oleh Partai Sosialis Italia (Patria \& Arief, 2015).

Pada bulan Mei 1919, Gramsci dan pemuda sosialis di Turin, seperti Tasca, Togliatti dan Terracini mendirikan L'Ordine Nuovo, sebuah koran mingguan yang ditujukan sebagai organ kebudayaan proletar. Media ini, melalui ide-ide politiknya mendorong dan merekomendasi dilakukannya pemberontakan buruh militan di Italia Utara. Gramsci meyakini bahwa kapitalisme telah menjadi matang sehingga titik transisi menuju komunisme bisa terjadi.

Italia setelah Perang Dunia I juga mengalami pertarungan politik partai, baik partai kanan ataupun kiri. Pada 1921, Partai Komunis Italia (PCI) didirikan secara terbuka. Selanjutnya, Mussolini, mantan sosialis revolusioner yang keluar dari partai pada awal Perang Dunia I, mendirikan fasci, sebuah kelompok tempur untuk melindungi veteran perang dan melawan usaha anti patriotik dari kelompok ekstrem kiri. Pada waktu itu banyak kalangan melihat bahwa fasisme (fascimo) yang dibentuk Mussolini adalah tindakan untuk mencegah revolusi komunis dan sebagai upaya mengatasi kelumpuhan politik partai-partai moderat. Pada Oktober 1922, fasisme memenangkan persaingan politik di Italia, dengan ditunjuknya Mussolini sebagai perdana menteri. Kemenangan fasisme melenyapkan hak-hak politik rakyat, termasuk hak para aktivis masa itu.

Pada 1924, Gramsci diangkat sebagai pimpinan PCI, setelah sebelumnya menjabat sebagai wakil PCI di Moskow pada tahun 1922-1923. Pada tahun 1926, Fasis Italia memberangus semua publikasi kelompok politik kiri, dan melakukan 
penangkapan besar-besaran terhadap tokoh-tokoh politik kiri, termasuk menangkap dan menahan Gramsci, yang baru dua tahun menjabat Sekretaris Jendral PCI.

Sebagai anggota kunci Partai Sosialis Italia dan kemudian pemimpin Partai Komunis Italia, Gramsci melihat kegagalan gerakan massa pekerja revolusioner, dan menjadi saksi bangkitnya fasisme reaksioner yang justru didukung oleh banyak massa kelas pekerja. Dua peristiwa tersebut sangat mempengaruhi perkembangan pemikiran Gramsci dan menyadarkannya bahwa meskipun kapitalisme telah berkembang menjadi matang, tetapi perubahan menuju komunisme hanya bisa terjadi jika kaum proletar sudah memiliki kesadaran terhadap kondisi-kondisi ini, serta mampu melakukan pengorganisasian internal agar mampu mengambil langkah selanjutnya secara mandiri. Sepanjang kaum proletar masih terhegemoni kelas borjuis, maka gerakan radikal pekerja untuk melakukan counter hegemoni tidak akan tercapai.

Berkaca dari kegagalan gerakan pekerja, Gramsci menggagas pandangan alternatif marxisme tentang negara, yaitu suatu kesatuan kompleks dari kegiatan teori dan praktik, yang dengannya kelas yang berkuasa tidak hanya membenarkan dan memelihara dominasi, tetapi juga berusaha memenangkan konsensus aktif dari yang didominasi (Suyanto \& Amal, 2010).

\section{b. Pemikiran Politik dan Teori Sosial yang Mempengaruhi}

Gramsci adalah seorang sosialis, karenanya pemikiran-pemikiran Marx dan Engels sedikit banyak mempengaruhi pemikiran politik Gramsci. Pemikiran Marxisme klasik yang dikembangkan Marx dan Engels, yang cenderung memandang institusi-institusi politik sebagai cerminan struktur ekonomi, menjadi titik perhatian Gramsci. Pandangan yang disebut ekononisme ini, dinilai menghalangi pemahaman tentang watak dominasi kapitalis dan strategi yang dibutuhkan untuk mengakhiri dominasi dan bergerak menuju sosialisme. Lenin mengajukan kritik tajam terhadap Marxisme klasik, tetapi pemikiran Gramsci lah yang menyempurnakan kelemahankelemahan kritik Lenin terhadap ekonomisme.

Ekonomisme adalah Marxisme yang meyakini bahwa perkembanganperkembangan politik adalah wujud dari perkembangan-perkembangan ekonomi. Ekonomisme mengemukakan metaphor 'struktur dasar' dan 'struktur atas' (base and 
super structure), dan menyatakan bahwa perkembangan yang terpenting adalah perkembangan yang berlangsung dalam struktur dasar ekonomi, sedangkan perkembangan politik dipandang sebagai bagian dari struktur atas, yang perkembangannya tergantung pada struktur dasar.

Salah satu bentuk ekonomisme adalah pandangan bahwa sejarah bergerak secara otomatis dan tidak terhindarkan, mengikuti pertumbuhan dan perkembangan kekuatan-kekuatan produksi yang terus berlangsung. Ekonomisme meyakini bahwa kapitalisme akan menuju krisis dan kehancurannya sendiri disebabkan oleh perkembangan dan pertentangan kekuatan-kekuatan dan hubungan produksi dalam system kapitalisme yang terus membesar. Salah satu asumsi dalam ekonomisme adalah bahwa kaum proletar dalam system kapitalis makin lama akan makin dimiskinkan, dan pada akhirnya akan memberontak dan mengobarkan revolusi untuk mengakhiri situasi yang menyengsarakan tersebut. Revolusi proletar dipandang sebagai sesuatu yang tak terhindarkan, dan para penganut komunisme harus menunggu situasi revolusioner tersebut dan bersiap bertindak ketika situasi itu terjadi.

Gramsci menyebut ekonomisme sebagai determinisme mekanis, dan dalam pandangannya determinisme mekanis melahirkan sikap pasif. Keyakinan bahwa kontrakdiksi dalam kapitalisme akan berkembang, dan gerakan massa revolusioner akan muncul dengan sendirinya dan mengantarkan pada sosialisme, menyebabkan kaum pekerja hanya menunggu keruntuhan ekonomi kapitalis dan tidak siap dengan inisiatif-inisiatif politis.

Gramsci menganggap bahwa pandangan ekonomistis inilah yang menjadi penyebab utama kegagalan Partai Sosialis Italia dalam mengobarkan revolusi kaum pekerja pada tahun 1912-1920, dan yang mengakibatkan timbulnya sikap pasif dalam menghadapi fasisme di Italia. Dua kejadian penting dalam sejarah politik di Italia ini sangat mempengaruhi pemikiran Gramsci dan menjadi cikal bakal kelahiran teori hegemoni Gramsci.

Sebelum Gramsci, Lenin telah meletakkan dasar-dasar konsep hegemoni. Bagi Lenin, hegemoni adalah strategi revolusi yang harus dijalankan oleh kelas pekerja dan anggota-anggotanya untuk memperoleh dukungan mayoritas. Ketika revolusi 
untuk menggulingkan kekuasaan bangsa Tsar terjadi di Rusia, kelas pekerja yang merupakan kelompok minoritas beraliansi dengan para petani yang merupakan mayoritas penduduk, dan kelompok pekerja bertindak sebagai kekuatan utama (hegemonik).

Gramsci memperluas pengertian hegemoni Lenin, sehingga hegemoni juga mencakup peran kelas kapital dan anggotanya, baik dalam merebut kekuasaan negara maupun dalam mempertahankan kekuasaan yang sudah dimiliki. Selanjutnya, jika bagi Lenin hegemoni utamanya dipahami dalam pengertian aliansi antar kelas atau kelompok kelas, maka Gramsci menambahkan dimensi nasional kerakyatan dalam konsep hegemoni. Gramsci menyatakan bahwa suatu kelas tidak dapat meraih kepemimpinan nasional dan menjadi hegemonik, jika kelas itu hanya memperhatikan kepentingan mereka sendiri, karenanya mereka harus juga memperhatikan tuntutan dan perjuangan rakyat yang tidak mempunyai karakter kelas yang bersifat murni, yaitu kepentingan yang tidak muncul secara langsung dari hubungan-hubungan produksi. Dengan demikian, hegemoni mempunyai dimensi kelas dan dimensi nasional kerakyatan.

Selanjutnya, pemikiran Benedetto Croce, seorang filsuf Italia (1866-1952), penganut marxisme yang mendominasi kehidupan intelektual di negaranya selama periode awal abad dua puluh, juga banyak mempengaruhi pemikiran Gramsci. Croce adalah filsuf yang idealistis dan menaruh perhatian pada peran kesadaran manusia dalam membentuk dunia. Istilah idealismee diartikan sebagai suatu sudut pandang yang menekankan peran ide-ide dan nilai-nilai moral dalam memahami dan menjelaskan perubahan-perubahan historis. Nilai-nilai moral dan ide-ide dianggap sebagai faktor yang paling penting untuk memotivasi orang bertindak. Pandangan idealisme dikontraskan dengan materialisme, yang berpendapat bahwa tindakan yang memunculkan perubahan besar dalam sejarah disebabkan oleh kepentingan ekonomi berbagai kelas. Dalam pandangan Marxis Materialis, idealisme meremehkan determinasi material dan ekonomi yang beroperasi dalam semua situasi sejarah.

Sudut pandang idealisme dan materialisme ditolak oleh Gramsci. Gramsci memilih sudut pandang 'materialismee dialektis', yang dikembangkan Marx. Marx dan Gramsci sama-sama bermaksud menekankan sisi material dan praktis atas proyek-proyek manusia, sekaligus mencoba mempertahankan sisi aktif idealisme, 
yaitu peran kesadaran manusia dalam mentransformasikan alam dan masyarakat. Marx dan Gramsci menghindari peran pasif murni, tidak seperti para filsuf idealis yang tetap berada pada tingkat abstrak dalam bersilsafat, dan tidak berusaha mencapai idea mereka dalam situasi yang nyata. Namun demikian, jika Marx memberikan bobot yang lebih berat pada materialisme, maka Gramsci memberikan bobot yang lebih berat pada idealisme. Pada titik inilah pemikiran Croce berperan dalam mempengaruhi pemikiran Gramsci.

Gramsci menganggap serius penekanan Croce pada peran kesadaran manusia dalam membentuk sejarah, tetapi Gramsci menganggap Croce sebagai filsuf yang spekulatif karena pemikiran-pemikiran filsafatinya tidak pernah diwujudkan dalam bentuk konkret. Kritik Gramsci terhadap Croce, membawanya pada kesimpulan bahwa masyarakat dapat dan seharusnya mengontrol sejarah melalui tindakantindakan politik konkret untuk mencapai perubahan-perubahan yang diinginkan. Gramsci juga menyatakan bahwa masyarakat perlu mengetahui situasi ekonomi, politik, dan militer sebelum memulai gerakan yang sia-sia.

\section{c. Latar Belakang Kehidupan Pribadi Gramsci}

Secara sederhana, kehidupan Gramsci terbagi dalam tiga fase. Fase pertama adalah masa kecilnya di Sardinia sampai masa studinya di Universitas Turin (18911918), fase kedua adalah tahun-tahun aktifitas politik Gramsci (1918-1926), dan fase ketiga adalah tahun-tahun Gramsci dipenjara, dan melahirkan pemikiran-pemikiran puncaknya (1926-1937). Berikut ini, akan dipaparkan secara ringkas riwayat dan latar belakang kehidupan Gramsci.

Gramsci lahir dari keluarga kelas bawah, 22 Januari 1891, di Ales, Propinsi Cagliari, Sardinia. Gramsci adalah anak keempat dari tujuh bersaudara pasangan Francesco Gramsci, seorang pegawai kantor panitera daerah di Ghilarza, dengan Giusppina Marcias. Pada tahun 1897, saat Gramsci berusia 6 tahun, ayahnya ditangkap dan dipenjara selama lima tahun atas tuduhan korupsi, sehingga keluarga Gramsci jatuh miskin. Ibunya, Giusppina membawa anak-anaknya pindah ke Ghilarza, tempat dimana Antonio Gramsci menyelesaikan Sekolah Dasar. Selepas $\mathrm{SD}$, karena kemiskinan keluarga, Gramsci sempat berhenti sekolah selama dua tahun 
untuk bekerja, sebelum akhirnya Gramsci belajar secara otodidak dan mengambil kelas-kelas tata bahasa.

Pada 1908, Gramsci memulai sekolah menengah di Cagliari, dan tinggal bersama kakak lelakinya, Gennaro, seorang sosialis militan yang memperkenalkannya pada politik. Tahun 1911, saat berusia 20 tahun, Gramsci menyelesaikan Sekolah Menengah, dan berhasil mendapat beasiswa di Fakultas Sastra, Universitas Turin. Di sinilah, Gramsci bersahabat dengan Angelo Tasca, seorang pemimpin muda gerakan Pemuda Sosialis, yang membuatnya makin terlibat dengan dunia politik.

Sejak duduk di bangku kuliah, Gramsci sudah sangat tertarik pada gerakan sosial dan sangat terkesan dengan gerakan kaum pekerja di Turin. Minat ini mendorongnya bergabung dengan Partai Sosialis Italia (PSI) di tahun 1913. Selanjutnya, Gramsci memulai kehidupannya sebagai seorang aktivis dengan bekerja sebagai editor, kolumnis dan analis di harian sosialis Il Grido del Papulo dan Avanti! Keterlibatan dan pengalamannya di bidang media dan politik membuahkan hasil. Pada tahun 1919, dalam usinya yang masih muda, 28 tahun, Gramsci telah dipercaya untuk memimpin sebuah mingguan ternama kaum sosialis yang disegani di Turin, L'Ordine Nuovo.

Pada tahun 1922, Gramsci pindah ke Moskow dan bekerja sebagai anggota ekskutif Komintern Internasional Komunis. Kemudian pada tahun 1923, Gramsci pindah ke Wina dan banyak melibatkan diri dalam perdebatan-perdebatan kritis untuk membahas strategi baru partai, serta melancarkan banyak kritik terhadap perkembangan sosialisme dan komunisme di Uni Soviet. Gramsci mulai mengkhawatirkan perkembangan sosialisme dan komunisme, dan mengemukakan gagasan tentang bagaimana watak demokratis dalam sosialisme harus diterapkan.

Pada 1924, Gramsci kembali ke Italia dan diangkat sebagai anggota parlemen mewakili golongan sosialis. Sebagai pemimpin Partai Komunis Italia, Gramsci melakukan berbagai upaya untuk melakukan perubahan dan transformasi terhadap Partai Komunis, serta mengembangkan Partai Komunis sebagai partai yang berakar pada gerakan massa.

Tahun 1926 adalah tahun paling menyedihkan bagi perjalanan hidup Gramsci sebagai aktivis. Gramsci ditahan dan dijatuhi hukuman penjara selama 20 tahun, 4 bulan, 15 hari. Sejak mendapatkan ijin untuk menulis pada tahun 1929, Gramsci mulai menuangkan pemikiran-pemikirannya dalam catatan-catatan harian. Pemikiran 
Gramsci yang mula-mula dituliskan ketika dipenjara adalah pemikiran tentang peran kaum intektual dalam transformasi sosial. Sesudahnya muncul konsep-konsep pemikiran yang lainnya tentang hegemoni, negara, civil society, yang dianggap sangat brilian. Selama masa hukumannya di penjara, Gramsci berhasil menuliskan 34 buku catatan harian, yang masing-masing membahas satu pokok bahasan. Catatancatatan inilah yang kemudian diterbitkan dalam buku The Prison Notebook.

Joseph Femia dalam bukunya, Gramsci's Political Thouht: Hegemony, Conciousness and the Revolutionary Process (Patria \& Arief, 2015), memilah kehidupan politik dan perkembangan pemikiran Gramsci dalam empat fase. Fase pertama terentang antara tahun 1914-1919, yang merupakan tahun-tahun pembentukan wawasan politik dan intektual Gramsci. Gramsci pada masa ini adalah sosialis muda yang sangat idealis. Tulisan-tulisannya yang dimuat di koran sosialis Avanti dan Il Grido del popolo, mengungkapkan banyak hal tentang kondisi-kondisi budaya dan keinginannya menanamkan kesadaran terhadap kaum buruh melalui pendidikan.

Fase kedua berlangsung sekitar tahun 1919-1920, masa dimana Italia dilanda banyak kekacauan di pabrik dan aksi pemogokan buruh. Gramsci terlibat dalam gerakan buruh secara besar-besaran di Turin dengan menjadi teoritisi utama gerakan Dewan Pabrik (the factory council's movement). Fase ketiga, antara tahun 19211925, adalah masa ketika Gramsci mulai menjadi pengurus Partai Komunis Italia (yang mencapai puncaknya ketika diangkat menjadi Sekretaris Umum PKI (19241926)), hingga masuknya Gramsci sebagai tahanan politik rezim fasis Mussolini.

Fase terakhir, tahun 1926-1937, adalah masa-masa Gramsci dijatuhi hukuman penjara selama 20 th, sampai meninggal tahun 1937 karena pendarahan otak. Pada fase ini Gramsci menganalisis secara mendalam pengalaman politiknya dalam kerangka historis maupun filosofis. Antara tahun 1929-1935, Gramsci menyelesaikan 32 catatannya yang mencapai hamper 3000 halaman. Inilah fase terpenting yang mengembangkan pemikiran Gramsci.

\section{d. Pertanyaan Teoritis yang Diajukan}

Sebagai seorang sosialis, Gramsci memimpikan masyarakat tanpa kelas, masyarakat dimana kaum pekerja tidak lagi dieksploitasi dan didominasi kaum 
borjuis, karenanya pemikiran-pemikiran Gramsci secara umum bertumpu pada pertanyaan seputar bagaimana cara melahirkan masyarakat sosialis yang bebas dari dominasi dan eksploitasi.

Secara khusus Gramsci mempertanyakan mengapa terjadi kesenjangan antara teori Marxis dengan praktik politik kaum pekerja? Dengan kata lain, mengapa kekuatan kaum borjuis tidak berakhir, sementara Gramsci sendiri meyakini bahwa kapitalisme telah matang dan prakondisi sosial serta ekonomi untuk transisi menuju sosialisme telah siap? Gramsci juga mempertanyakan, bagaimana caranya menutup kesenjangan tersebut? Dengan strategi apa sebuah partai revolusioner menumbuhkan dukungan dan mencapai kekuatan penuh dalam masyarakat kapitalisme yang telah maju? Pertanyaan Gramsci ini adalah upayanya mencari jawaban atas kegagalan strategi kaum pekerja dalam menumbangkan kaum borjuis di Italia, yang justru dibarengi dengan menguatnya kekuatan fasisme. Gramsci mempertanyakan, mengapa masyarakat Italia justru mendukung fasisme dan bukannya sosialisme? Mengapa di Italia, pihak yang berkuasa, baik negara maupun kaum borjuis mampu mendapatkan konsensus atas kekuasaannya terhadap mayoritas masyarakat? Pertanyaan-pertanyaan teoritis inilah yang menuntun pemikiran Gramsci dalam melahirkan Teori Hegemoni.

\section{e. Jenis Penjelasan yang Ditawarkan Teori Hegemoni Gramsci}

Teori Hegemoni sesungguhnya adalah kritik terhadap konsep pemikiran yang mereduksi dan menganggap esensi suatu entitas tertentu sebagai satu-satunya kebenaran mutlak, utamanya reduksionisme dan esensialisme yang melekat pada pemikiran-pemikiran penganut Marxisme dan Non Marxisme. Di kalangan penganut Marxisme telah lama terjadi perdebatan tentang konsep basic structure (ekonomi) dan superstructure (ideology, politik, pendidikan, budaya, dan sebagainya), dimana tafsiran Marxisme Klasik percaya bahwa strukstur dasar ekonomi menentukan super struktur. Sosialisme oleh kalangan tradisional direduksi menjadi ekonomisme. Perjuangan kelas direduksi menjadi perjuangan kelas ekonomi saja, sehingga hanya menjadi gerakan pekerja semata, dan mengabaikan gerakan lain seperti civil right movement, gerakan perempuan, gerakan budaya, lingkungan dan gerakan sosial lainnya. Pemikiran Gramsci membukakan kesadaran tentang gerakan pekerja sebagai bagian dari gerakan masyarakat sipil (civil society) dan sebaliknya. 
Pemikiran Gramsci juga merupakan kritik terhadap pemikiran para penganut Marxisme Klasik yang cenderung positivistic dan mekanistik, utamanya dalam memandang perubahan sosial dan revolusi. Kecenderungan positivistic kalangan Marxis adalah pandangan tentang formasi sosial masyarakat yang meyakini bahwa masyarakat berkembang dan berubah secara linier, dari masyarakat primitif ke masyarakat feodal, kemudian menuju masyarakat kapitalistik yang mekanisme ekspolitatifnya menekan pekerja, sehingga menimbulkan revolusi yang akhirnya mendorong terwujudnya masyarakat yang sosialistik. Gramsci dalam analisisnya menunjukkan bahwa formasi sosial kapitalistik yang eksploitatif dan penindasan politik rezim fasisme Mussolini tidak secara otomatis melahirkan revolusi sosial, dan bahkan memunculkan gejala menguatnya 'de-ploletarisasi', dimana kaum pekerja rela menerima penderitaan, bahkan mendukung keberadaan rezim Mussolini. Reaksi intelektual Gramsci atas realitas inilah, yang antara lain mempengaruhi kelahiran Teori Hegemoni. Teori ini pada dasarnya adalah antitesa atas model perubahan sosial yang sangat positivistic dalam teori Marxisme saat itu.

Titik awal konsep Gramsci tentang hegemoni adalah bahwa suatu kelas dan anggotanya menjalankan kekuasaan terhadap kelas-kelas di bawahnya dengan cara kekerasan dan persuasi. Hegemoni bukan hubungan dominasi dengan menggunakan kekuasaan, tetapi hubungan persetujuan dengan mengunakan kepemimpinan politik dan ideologis. Dengan demikian, berbeda dengan makna aslinya dalam bahasa Yunani yang berarti penguasaan satu bangsa atas bangsa lainnya, hegemoni dalam pengertian Gramsci adalah sebuah organisasi konsensus dimana ketertundukan diperoleh melalui penguasaan ideologi dari kelas yang menghegemoni ${ }^{1}$.

Ketika Gramsci berbicara tentang konsensus, dia mengaitkannya dengan spontanitas yang bersifat psikologis yang mencakup berbagai penerimaan aturan sosiopolitis ataupun aspek-aspek aturan lainnya. Konsensus bisa terjadi; 1) karena rasa takut akan konsekuensi-konsekuensi bila tidak menyesuaikan diri, 2) karena terbiasa mengikuti tujuan-tujuan dengan cara-cara tertentu, dan 3) karena kesadaran atau persetujuan terhadap unsur tertentu. Konsensus menurut Gramsci adalah konsensus yang tercipta karena ada dasar persetujuan. Bagi Gramsci, sebuah konsensus yang diterima kelas pekerja pada dasarnya bersifat pasif, artinya

${ }^{1}$ Simon, Roger. 2004. Gagasan-Gagasan Politik Gramsci, Yogyakarta, Pustaka Pelajar. 
konsensus terjadi bukan karena kelas pekerja menganggap struktur sosial yang ada itu sebagai keinginannya, tetapi lebih karena mereka kekurangan basis konseptual yang memungkinkan mereka memahami realitas sosial secara efektif.

Dua hal disebut Gramsci sebagai penyebab kurangnya basis konseptual kaum buruh, yaitu pendidikan dan mekanisme kelembagaan. Pendidikan yang ada tidak membangkitkan kemampuan kaum buruh untuk berfikir kritis dan sistematis. Di lain pihak, mekanisme kelembagaan (sekolah, gereja, partai-partai politik, media massa, dan sebagainya), menjadi kaki tangan kelompok yang berkuasa untuk menentukan ideology yang mendominasi. Gramsci menarik kesimpulan bahwa watak sebuah konsensus dalam masyarakat kapitalis sesungguhnya adalah kesadaran yang bertentangan (contradictory consciousness). Dengan demikian, hegemoni yang dilakukan oleh kelas borjuis adalah hasil konsensus yang samar-samar. Berdasar realitas ini, Gramsci mengemukakan tiga tingkatan hegemoni, yaitu hegemoni integral (integral), hegemoni yang merosot (decadent), dan hegemoni yang minimum (Patria \& Arief, 2015).

Hegemoni total (integral), ditandai dengan afiliasi massa yang mendekati total. Masyarakat menunjukkan tingkat kesatuan moral dan intelektual yang kokoh, yang tampak dari hubungan organis pemerintah dan yang diperintah. Hubungan tersebut tidak diwarnai kontradiksi dan antagonism baik secara sosial maupun etis. Hegemoni yang merosot (decadent), ditandai dengan adanya potensi disintegrasi atau potensi konflik yang tersembunyi di bawah permukaan, artinya meskipun sistem yang ada telah mencapai kebutuhan dan sasarannya, tetapi mentalitas massa tidak sungguhsungguh selaras dengan pemikiran yang dominan dan subyek hegemoni. Hegemoni minimum, adalah hegemoni yang bersandar pada kesatuan ideologis antara elit ekonomi, politik dan intelektual, yang berlangsung bersamaan dengan keengganan terhadap setiap campur tangan massa dalam hidup bernegara. Kelompok-kelompok hegemonis tidak mau menyesuaikan kepentingan dan aspirasinya dengan kelas lain dalam masyarakat.

Gramsci, dalam membicarakan hegemoni memberikan tiga batasan konseptualisasi, yaitu ekonomi, masyarakat politik (political society) dan masyarakat sipil (civil society). Ekonomi, adalah batasan yang digunakan untuk mengartikan mode of production yang paling dominan dalam sebuah masyarakat. Cara produksi 
tersebut terdiri dari tehnik produksi dan hubungan sosial produksi yang tumbuh karena munculnya perbedaan kelas-kelas sosial, dalam arti kepemilikan produksi.

Masyarakat politik (political society) merupakan tempat berlangsungnya birokrasi negara dan tempat munculnya praktek-praktek kekerasan negara. Birokrasi negara, dalam pemahaman Gramsci diidentifikasikan sebagai pelayanan sipil, kesejahteraan dan institusi pendidikan. Gramsci memakai istilah masyarakat politik untuk menunjuk hubungan-hubungan koersif yang terwujud dalam berbagai lembaga negara - angkatan bersenjata, polisi, lembaga hukum dan penjara, bersama dengan semua departemen administrasi yang mengurusi pajak, keuangan, perdagangan, industri, keamanan sosial, dan sebagainya. Gramsci menyatakan bahwa aktifitas negara tidak hanya sekedar melakukan tindakan koersif, tetapi juga berperan dalam membangun konsensus melalui pendidikan dan fungsi kelembagaan.

Selanjutnya, masyarakat sipil (civil society) menunjuk pada organisasi lain, selain negara, dan di luar system produksi material dan ekonomi, yang didukung dan dilaksanakan oleh orang atau komponen di luar system produksi dan negara. Komponen utama masyarakat sipil didefinisikan sebagai sebuah institusi religious (Patria \& Arief, 2015). Dalam suratnya tanggal 7 September 1931, Gramsci menunjukkan bahwa masyarakat sipil mencakup apa yang disebut organisasiorganisasi swasta (private), seperti gereja, serikat dagang, sekolah, dan sebagainya. Gramsci juga menambahkan bahwa dalam masyarakat sipil lah kaum intelektual menjalankan tugasnya secara khusus.

Yang perlu digarisbawahi dari batasan konseptualisasi tersebut adalah bahwa pemilahan antara masyarakat politik dan masyarakat sipil tidak harus dipahami seolah-olah keduanya terpisah dalam batas-batas yang tegas. Pada dasarnya keduanya terbentuk dari berbagai hubungan sosial, yang kemudian menjelma menjadi berbagai organisasi, sehingga dimungkinkan terjadi tumpang tindih.

Gramsci kemudian juga memunculkan konsep baru mengenai negara, yaitu konsep negara integral, atau negara yang diperluas. Negara integral merupakan hasil perpaduan antara masyarakat politik (political society) yang menjadi sumber koersi dalam masyarakat, dan masyarakat sipil (civil society) dimana kepemimpinan hegemonik terbangun. Negara integral merupakan hegemoni yang diselubungi 
kekuasaan koersi. Berbeda dengan negara totaliter yang tidak memiliki unsur sukarela, tetapi kaya dengan paksaan, negara integral masih menyediakan peluang untuk menghasilkan persetujuan sukarela tanpa dipaksa.

Konsep Gramsci tentang negara integral menunjukkan bahwa kekuasaan tidak hanya terpusat pada negara. Kekuasaan dipahami sebagai suatu hubungan, sehingga hubungan sosial masyarakat sipil juga merupakan hubungan kekuasaan. Konsep Gramsci tentang kekuasaan ini berbeda dengan dengan konsep marxisme klasik, termasuk Lenin, yang melihat kekuasaan terpusat pada negara dan berada di bawah control penuh kelas pemiliki kapital.

Selanjutnya, Gramsci menyatakan bahwa di mana ada kekuasaan, di sana muncul perlawanan terhadapnya. Dalam masyarakat kapitalis yang sudah maju, dimana masyarakat sipilnya sudah berkembang, diperlukan strategi yang berbeda untuk melawan kekuasaan dominan. Gramsci menyebut strategi ini dengan istilah perang posisi (war position). Dalam perang posisi, kelas pekerja harus membongkar system pertahanan yang mendukung hegemoni kelas borjuis, dengan cara membangun aliansi dengan semua gerakan sosial yang sedang berusaha mengubah relasi-relasi dalam masyarakat sipil. Kekuasaan hegemoni kaum borjuis melalui organisasiorganisasi dalam masyarakat sipil harus terus dilemahkan dengan menghimpun kekuatan balik di bawah pimpinan kelas pekerja.

Peran intelektual dalam masyarakat sipil dan dalam transisi menuju sosialisme, adalah tema yang dibahas secara luas dalam catatan-catatannya di penjara. Ada dua tema penting dari pandangan Gramsci tentang intelektual. Pertama, tentang perlunya menghapus perbedaan antara kerja manual dan kerja intelektual yang telah berlangsung lama di bawah kapitalisme, baik dalam proses produksi, dalam masyarakat politik dan masyarakat sipil. Kedua, tentang hubungan antara pengetahuan dan kekuasaan, atau tentang kekuasaan yang lahir dari monopoli pengetahuan oleh kelas yang berkuasa, dan perlunya perubahan mendasar dalam hubungan antara manusia dan pengetahuan dalam transisi menuju sosialisme.

Gramsci menolak pandangan tradisional yang menganggap bahwa intelektual hanya terdiri dari ahli sastra, filosof dan seniman. Intelektual tidak dicirikan oleh aktifitas berpikir yang dimiliki oleh semua orang, tetapi oleh fungsi yang mereka 
jalankan. Oleh karenanya Gramsci menyatakan bahwa semua orang adalah intelektual, namun tidak semua orang mempunyai fungsi intelektual. Kaum intelektual menurut Gramsci adalah semua orang yang mempunyai fungsi sebagai organisator dalam semua lapisan masyarakat, dalam wilayah produksi, politik dan kebudayaan. Kaum intelektual bukan hanya pemikir, penulis, dan seniman, tetapi juga organisator seperti pegawai negeri, pemimpin politik, dan mereka yang berguna dalam masyarakat sipil, negara, dan system produksi seperti ahli mesin, manager dan tehnisi.

Selanjutnya Gramsci membuat perbedaan antara intelektual organik dan intelektual tradisonal. Intelektual tradisional adalah mereka yang menjadi intelektual organik dalam model produksi feodal yang telah digantikan, atau menjadi intelektual organik dalam model produksi yang sedang dalam proses digantikan. Dengan demikian, dari sudut pandang kelas pekerja, semua intelektual organik dari kelas kapitalis adalah intelektual tradisional.

Intelektual organik adalah intelektual dan organisator politik, yang menyadari identitas yang diwakili dan yang mewakili, serta merupakan barisan terdepan yang riil dan organik dari lapisan kelas ekonomi atas. Fungsi yang dijalankan oleh intelektual organik kelas kapitalis adalah bertindak sebagai agen kelas untuk mengorganisir hegemoni dalam masyarakat sipil dan mendominasi melalui aparat negara. Dengan demikian, para manager, insinyur, tehnisi yang terkemuka adalah intelektual organik dalam bidang produksi. Politisi, penulis, akademisi, penyiar, wartawan, yang terkemuka dan mempunyai pengaruh luas adalah intelektual organik dalam masyarakat sipil. Sedangkan, pegawai negeri senior, perwira papan atas dalam dinas ketentaraan, jaksa dan hakim di Pengadilan Tinggi, adalah intelektual organik dalam negara. Gramsci menyatakan, jika kelas pekerja ingin beranjak dari kelas rendah untuk mengambil kepemimpinan bangsa, dan membangun kesadaran politik melalui reformasi moral dan intelektual, maka mereka harus menciptakan kelas intelektual organiknya sendiri.

Intelektual baru yang dibutuhkan oleh kelas pekerja berbeda dengan intelektual kelas borjuis. Gramsci berpendapat bahwa partai revolusioner lah yang memainkan peran kunci sebagai intelektual organik kelas pekerja. Setiap anggota partai harus dianggap sebagai seorang intelektual organik, apapun tingkat pendidikannya. Partai 
revolusioner dalam pemahaman Gramsci adalah barisan depan kaum proletariat, yang bertugas mengorganisir dan menyatukan semua kekuatan yang diperlukan bagi sebuah revolusi, serta memimpin pemberontakan menentang negara borjuis untuk mendirikan negara pekerja (Simon, 2004). Menurut Gramsci, dalam upaya menyatukan semua kekuatan, partai revolusioner harus mengambil inisiatif politik dan membangun hubungan kerjasama dengan pekerja dan petani, serta organisasi mereka. Partai revolusioner juga bertanggungjawab memimpin reformasi intelektual dan moral, sebagai langkah meraih hegemoni dan transisi menuju sosialisme. Reformasi intelektual dan moral adalah perjuangan ideologis untuk mengubah kesadaran rakyat dan membangun pandangan baru tentang nilai-nilai sosialis.

\section{f. Kata Kunci dan Proposisi}

Hegemoni (egemonia), dalam bahasa aslinya, Yunani, berarti penguasaan satu bangsa atas bangsa lainnya. Hegemoni dalam pengertian Gramsci adalah sebuah konsensus dimana ketertundukan diperoleh melalui penerimaan ideologi kelas yang menghegemoni oleh kelas yang terhegemoni. Hegemoni bukan hubungan dominasi dengan menggunakan kekuasaan, tetapi hubungan persetujuan dengan mengunakan kepemimpinan politik dan ideologis. Hegemoni adalah kemenangan kelas yang berkuasa yang didapatkan melalui mekanisme konsensus berbagai kekuatan sosial politik.

Hegemoni berlangsung ketika masyarakat bawah termasuk kaum proletar sudah menerima dan meniru cara hidup, cara berpikir, dan pandangan kelompok elit yang mendominasi dan mengeksploitasi mereka. Hegemoni, menurut Gramsci, akan melahirkan kepatuhan, sebuah sikap menerima keadaan tanpa mempertanyakannya lagi secara kritis karena ideologi yang diekspos kelas hegemonik hanya ditelan mentah-mentah.

Suatu kelompok kelas dikatakan hegemonik manakala kelompok kelas tersebut mendapatkan persetujuan dari kekuatan dan kelas sosial lainnya, dengan cara menciptakan dan mempertahankan sistem aliansi melalui perjuangan politik dan ideologis. Menurut Gramsci, kelas pekerja hanya bisa menjadi kelas hegemonik dengan cara memperhatikan berbagai kepentingan dari kelas dan kekuatan sosial lain, serta mempertemukannya dengan kepentingan mereka sendiri. Kepentingan 
tersebut tidak boleh sebatas kepentingan lokal yang disebut Gramsci sebagai perjuangan ekonomi korporasi (economic corporate strunggle). Mereka juga harus mencapai berbagai konsensus agar bisa mewakili semua kelompok kekuatan yang lebih besar. Upaya mencapai konsensus dilakukan melalui perjuangan politik dan kepemimpinan intelektual, serta penyadaran ideologi melalui pendidikan dan mekanisme kelembagaan.

Strategi membangun suatu kelompok besar yang terdiri dari berbagai kekuatan sosial yang disatukan dengan konsepsi yang sama tentang dunia disebut Gramsci sebagai perang posisi (war of position). Dalam menganalisis perang posisi antara dua kelas utama untuk meraih hegemoni, Gramsi membedakan strategi-strategi yang dilakukan kaum borjuis dan kaum pekerja. Revolusi pasif (passive revolution) adalah strategi yang diterapkan kaum borjuis untuk meraih hegemoni dimana pemain utamanya bukanlah rakyat, tetapi revolusi dari atas. Revolusi pasif merupakan respon khas kaum borjuis ketika hegemoni yang mereka kembangkan sebelumnya terancam, sehingga perlu dilakukan proses pengorganisasian kembali secara menyeluruh untuk mendapatkan kembali kekuatan hegemoniknya. Sebaliknya, kelas pekerja menjalankan revolusi anti pasif (anti-passive revolution) sebagai strategi untuk meraih hegemoni dengan cara memperkuat perjuangan kelas yang bersifat demokratis kerakyatan secara terus menerus.

Tujuan menciptakan hegemoni baru hanya dapat diraih dengan mengubah kesadaran, pola pikir, pemahaman dan konsepsi masyarakat tentang dunia, serta mengubah norma perilaku moral mereka. Gramsci menyebut gerakan ini sebagai revolusi intelektual dan moral. Kaum intelektual mengemban tugas untuk melaksanakannya. Gramsci meyakini bahwa setiap kelas menciptakan satu atau lebih strata kaum intektual yang sadar akan peranannya, yang bukan hanya dalam bidang ekonomi tetapi juga dalam lapangan politik dan sosial. Dengan demikian, kelas pekerja juga harus menciptakan kaum intelektualnya sendiri jika ingin menjadi kelas hegemonik.

Gramsci mendefinisikan kaum intelektual sebagai semua orang yang mempunyai fungsi sebagai organisator dalam semua lapisan masyarakat, dalam wilayah produksi, politk ataupun budaya. Intelektual bukan hanya pemikir, penulis, seniman, tetapi 
juga organisator seperti pegawai negeri dan pemimpin politik, serta para ahli yang terlibat dalam kegiatan produksi, seperti ahli mesin, manager dan tehnisi.

Gramsci menyadari bahwa hegemoni kaum borjuis tidak semata-mata berdasarkan daya ancam ekonomis dan politiknya, tetapi karena kaum borjuis mampu menciptakan alam pikiran dan sistem nilai yang diyakini oleh masyarakat. Kaum pekerja dan kaum tertindas mau menerima hegemoni kaum borjuis karena mereka menganggapnya wajar dan bahkan dianggap sebagai sesuatu yang sifatnya given. Ciri khas kekuasaan hegemoni adalah bahwa kekuasaan itu tertanam dalam keyakinan, cita-cita, dan pandangan normatif seluruh masyarakat.

Gramsci memahami bahwa masyarakat kapitalis merupakan hasil hubungan yang sangat kompleks, yang melibatkan gereja, partai politik, serikat dagang, media massa, lembaga kebudayaan, dan lembaga sukarela, termasuk juga melibatkan negara sebagai sebuah lembaga yang terpisah dari lembaga lainnya, karena negara memiliki monopoli dalam penggunaan kekuasaan. Negara atau disebut juga sebagai masyarakat politik (polical society), adalah semua institusi publik yang memegang kekuasaan untuk melaksanakan perintah atau hubungan-hubungan koersif yang terwujud dalam berbagai lembaga negara seperti angkatan bersenjata, polisi, lembaga hukum dan penjara, bersama dengan semua departeman administrasi yang mengurusi pajak, keuangan, perdagangan, industri, keamanan sosial, dan sebagainya.

Selanjutnya, semua hubungan sosial antara berbagai lembaga selain negara dalam masyarakat kapitalis, disebut Gramsci sebagai masyarakat sipil (civil society). Masyarakat sipil memiliki posisi dan peran penting dalam membentuk kesadaran massa, dan merupakan wadah dimana kelompok sosial yang dominan mengatur konsensus dan hegemoni. Masyarakat sipil sekaligus adalah wadah dimana kelompok-kelompok sosial yang lebih rendah (subordinat) menyusun perlawanan dan membangun hegemoni alternatif atau hegemoni tandingan (counter hegemony).

Cicil society dan political society adalah dua struktur utama dalam suprastuktur yang mewakili dua wilayah yang berbeda tetapi berkaitan, yaitu wilayah adanya kekuatan (force) dalam political society, dan wilayah adanya persetujuan dalam civil society. Political society merujuk pada keunggulan kelompok sosial melalui cara 
dominasi atau pemaksaan kehendak. Civil society merujuk pada keunggulan kelompok sosial melalui kepemimpinan intelektual dan moral.

Gabungan dari civil society dan political society, atau dengan kata lain, hegemoni yang dilindungi oleh tameng koersif, disebut negara integral. Negara integral adalah istilah yang digunakan Gramsci untuk menyebut negara sebagai sebuah kombinasi kompleks antara kediktatoran dan hegemoni, dimana kelas yang berkuasa tidak hanya mempertahankan dominasi tetapi juga berusaha untuk memenangkan persetujuan aktif dari mereka yang dikuasai.

Gramsci menyatakan bahwa kelas yang hendak meraih hegemoni dalam masyarakat sipil juga harus meraih kepemimpinan dalam bidang produksi, karena kaum borjuis juga melakukan kontrol yang ketat atas proses produksi, sehingga mereka pun dapat menjadi kelas hegemonik dalam masyarakat sipil dan meraih kekuasaan negara. Dengan demikian, bidang politik (perjuangan meraih kekuasaan negara), tidak bisa dipisahkan dengan bidang ekonomi. Gramsci menggunakan istilah blok historis (historic bloc) untuk menunjukkan upaya kelas hegemonik dalam memadukan kepemimpinan atas kekuatan kelompok sosial dalam masyarakat sipil dengan kepemimpinan dalam bidang produksi.

Dari berbagai kata kunci dan penjelasan yang dikemukakan Gramsci, beberapa proposisi dapat dirumuskan untuk menggambarkan teori hegemoni. Pertama, hegemoni adalah kemenangan kelas yang berkuasa yang didapatkan melalui mekanisme konsensus berbagai kekuatan sosial politik. Kedua, dalam mempertahankan kekuasaan dan dominasi yang dimilikinya, kaum borjuis (blok historis) terus mengembangkan usaha yang berkesinambungan untuk merevisi konsensus dan ketertundukan kelas proletar, terutama melalui pendidikan dan mekanisme kelembagaan. Tiga, krisis hegemoni pada kelas penguasa hanya dapat memunculkan aksi jika kesadaran massa yang terhegemoni sudah terbentuk, dan siap melakukan aksi. Perkembangan kesadaran kelas yang terhegemoni ini yang diyakini akan menghasilkan perubahan revolusioner. Empat, titik transisi menuju sosialisme dapat terjadi ketika kapitalisme telah berkembang pada taraf kematangannya, tetapi hanya bisa terjadi jika kaum proletar sudah mencapai kesadaran yang memadai terhadap kondisi yang ada, serta mampu mengorganisir diri secara internal untuk menentukan langkah selanjutnya (Suyanto \& Amal, 2010). 


\section{g. Jenis dan Lingkup Realitas Sosial Teori Hegemoni Gramsci}

Realitas sosial yang dikaji dalam teori hegemoni Gramsci adalah hubungan antara kelas kapitalis, kelas pekerja, dan negara. Hubungan yang dimaksud adalah hubungan kekuasaan dan dominasi yang dicapai melalui kekuatan koersif maupun consensus dalam masyarakat sipil maupun masyarakat politik atau negara. Jika ditilik dengan menggunakan paradigma ilmu sosial yang ditawarkan oleh Goerge Ritzer, maka jenis realitas yang dikaji dalam teori hegemoni termasuk dalam fakta sosial.

Ketika paradigma dalam ilmu sosial tidak lagi dibagi dalam tiga tipologi, fakta sosial, definisi sosial, dan perilaku sosial, tetapi bertambah dengan munculnya paradigm baru, yaitu paradigm kritis dari Mazhab Frankfurt, maka teori hegemoni dikategorikan sebagai teori berparadigma kritis, karena Teori Hegemoni sesungguhnya adalah kritik terhadap reduksionisme dan esensialisme yang melekat pada pemikiran-pemikiran penganut Marxisme dan Non Marxisme. Sosialisme oleh kalangan Marxis Klasik direduksi menjadi ekonomisme. Perjuangan kelas direduksi menjadi perjuangan kelas ekonomi saja, sehingga hanya menjadi gerakan pekerja semata, dan mengabaikan gerakan lain seperti civil right movement, gerakan perempuan, gerakan budaya, lingkungan dan gerakan sosial lainnya. Pemikiran Gramsci membukakan kesadaran tentang gerakan pekerja sebagai bagian dari gerakan masyarakat sipil (civil society) dan sebaliknya. Pemikiran Gramsci juga merupakan kritik terhadap pemikiran para penganut Marxisme Klasik yang cenderung positivistic dan mekanistik, utamanya dalam memandang perubahan sosial dan revolusi.

Teori hegemoni Gramsci adalah teori makro yang menganalisi hubunganhubungan antara system ekonomi produksi, negara (political society) dan masyarakat sipil (civil society). Hubungan yang menjadi titik analisa adalah hubungan kekuasaan dan dominasi yang diraih melalui mekanisme konsensus berbagai kekuatan sosial politik dalam masyarakat, dengan mengunakan kepemimpinan politik, dan revolusi intelektual serta moral. Gramsci dalam pembahasan teorinya, meletakkan kekuatan ide (ideology) dan kesadaran kolektif sebagai penggerak perubahan sosial, karenanya dapat dikatakan bahwa lingkup realitas sosial yang dikaji dalam teori hegemoni Gramsci bersifat makro subyektif.

\section{h. Aktor Otonom yang Menentukan Realitas Sosial}


Teori hegemoni sesungguhnya adalah kritik terhadap pemikiran para penganut Marxisme Klasik yang cenderung positivistik, deterministik dan mekanistik, utamanya dalam memandang perubahan sosial dan revolusi. Gramsci menolak keyakinan kalangan Marxis bahwa masyarakat berkembang dan berubah secara linier, otomatis dan tidak terhindarkan menuju komunisme. Gramsci dalam analisisnya menunjukkan bahwa formasi sosial kapitalistik yang eksploitatif dan penindasan politik tidak secara otomatis melahirkan revolusi sosial, dan bahkan memunculkan gejala menguatnya 'de-proletarisasi', dimana kaum pekerja rela menerima penderitaan, bahkan mendukung keberadaan rezim yang berkuasa. Karenanya, Gramsci mengakui arti penting struktur, khususnya ekonomi, tetapi ia tidak mempercayai bahwa faktor-faktor struktural akan mampu mendorong terjadinya gerakan massa tanpa melibatkan gagasan-gagasan kolektif. Gramsci menyimpulkan bahwa kesadaran kelas, kemampuan kaum proletar untuk mengorganisir diri secara internal, dan bukan kepasifan menunggu jatuhnya kapitalisme, tetapi keaktifan menciptakan inisiatif-inisiatif politik, yang akan menggerakkan massa dan menghasilkan perubahan revolusioner. Dengan demikian, aktor otonom dalam teori hegemoni adalah individu yang aktif dan sadar.

\section{i. Faktor yang Menentukan Realitas Sosial}

Di kalangan penganut Marxisme telah lama terjadi perdebatan tentang konsep basic structure (ekonomi) dan superstructure (ideology, politik, pendidikan, budaya, dan sebagainya). Tradisi Marxisme Klasik mempercayai ekonomisme, yang menyatakan bahwa perkembangan yang terpenting adalah perkembangan yang berlangsung dalam struktur dasar ekonomi (basic structure), sedangkan perkembangan politik dipandang sebagai bagian dari struktur atas (super structure), yang perkembangannya tergantung pada struktur dasar. Gramsci justru melihat bahwa faktor kesadaran atau super struktur justru memiliki peran paling penting dalam proses perubahan sosial. Jadi, berbeda dengan Marx yang meyakini bahwa body akan menentukan mind, Gramsci justru melihat bahwa antara mind dan body sebetulnya bersifat dialektis, dan dalam beberapa hal, mind-lah yang menentukan body.

\section{j. Metodologi}


Teori Hegemoni tidak lahir hanya dari kontemplasi, tetapi lahir dari pengalaman, pengamatan, dan interpretasi kehidupan sosial dan politik yang berlangsung di sekitar dan selama kehidupan Gramsci. Hasil pengalaman, pengamatan dan analisa tersebut ditulisnya dalam catatan-catatan selama dipenjara, hingga saat kematiannya. Pengalaman masa kecil hingga dewasa, keterlibatannya yang sangat aktif dalam dunia politik, organisasi partai dan gerakan-gerakan buruh, menjadi data utama dalam membangun teori hegemoni.

Posisinya sebagai seorang sosialis yang memimpikan masyarakat tanpa kelas, pengalaman masa kecilnya yang penuh penderitaan, dan keterlibatannya dalam gerakan-gerakan buruh yang gagal, diduga sedikit atau banyak mempengaruhi keberpihakan Gramsci pada nasib dan kelangsungan hidup kaum proletar. Keberpihakannya pada kaum proletar, nampaknya juga membuat Gramsci tidak mampu melihat secara lebih obyektif bahwa dominasi kekuatan borjuis telah benarbenar meluas dan mendalam, sehingga perubahan revolusioner dalam system kapitalisme yang sudah maju tersebut, hampir merupakan impian.

\section{KESIMPULAN}

Sebagai seorang sosialis, Gramsci meyakini bahwa masyarakat yang ideal adalah masyarakat sosialis, dimana kaum buruh tidak lagi menjadi korban eksploitasi dan dominasi kaum borjuis, serta tidak terpedaya oleh konsensus terselubung yang sengaja diciptakan kaum borjuis untuk mendapatkan ketertundukan kaum proletar.

Saat transisi menuju sosialisme akan terjadi ketika kapitalisme telah berkembang matang dan terjadi krisis hegemoni. Namun revolusi dan transisi hanya bisa terjadi jika kaum proletar sudah mencapai kesadaran yang memadai tentang kondisi yang ada, serta mampu mengorganisir diri secara internal untuk menentukan langkah selanjutnya. Jadi, sepanjang kaum proletar masih terhegemoni kelas borjuis, maka gerakan radikal pekerja untuk melakukan counter hegemoni dan revolusi tidak akan tercapai.

Menurut Gramsci, kelas pekerja hanya bisa menjadi kelas hegemonik dengan cara memperhatikan berbagai kepentingan dari kelas dan kekuatan sosial lain, serta 
mempertemukannya dengan kepentingan mereka sendiri. Kepentingan tersebut tidak boleh sebatas kepentingan lokal yang disebut Gramsci sebagai perjuangan ekonomi korporasi (economic corporate strunggle). Mereka juga harus mencapai berbagai konsensus agar bisa mewakili semua kelompok kekuatan yang lebih besar. Upaya mencapai konsensus dilakukan melalui perjuangan politik dan kepemimpinan intelektual, serta penyadaran ideologi melalui pendidikan dan mekanisme kelembagaan.

\section{DAFTAR PUSTAKA}

Bocock, Robert, 2007. Pengantar Komprehensif untuk Memahami Hegemoni, Yogyakarta, Jalasutra.

Gramsci, Antonio, 2013. Catatan-Catatan dari Penjara, Yogyakarta, Pustaka Pelajar.

Gramsci, Antonio, 2000. Sejarah dan Budaya, Surabaya, Pustaka Promethea.

Magnis Suseno, Franz. 2003. Dalam Bayangan Lenin, Enam Pemikir Marxisme dari Lenin sampai Tan Malaka, Jakarta, Gramedia.

Mills, C.Wright. 2003. Kaum Marxis, Ide-Ide Dasar dan Sejarah Perkembangannya, Yogyakarta, Pustaka Pelajar.

Patria, Nezar \& Arief, Andi, 2015. Antonio Gramsci, Negara dan Hegemoni, Yogyakarta, Pustaka Pelajar.

Simon, Roger, 2004. Gagasan-gagasan Politik Gramsci, Yogyakarta, Pustaka Pelajar.

Suyanto, Bagong \& Amal, Khusna, 2010. Anatomi dan Perkembangan Teori Sosial, Malang, Aditya Media Publising. 